\title{
Toward an integrated system of climate change and human health indicators: a conceptual framework
}

\author{
Ann Y. Liu ${ }^{1} \cdot$ Juli M. Trtanj ${ }^{2} \cdot$ Erin K. Lipp $^{3} \cdot$ John M. Balbus ${ }^{4}(1 D$ \\ Received: 17 November 2020 / Accepted: 17 May 2021/ Published online: 29 June 2021 \\ (C) This is a U.S. government work and not under copyright protection in the U.S.; foreign copyright protection may \\ apply 2021
}

\begin{abstract}
Environmental health indicators are helpful for tracking and communicating complex health trends, informing science and policy decisions, and evaluating public health actions. When provided on a national scale, they can help inform the general public, policymakers, and public health professionals about important trends in exposures and how well public health systems are preventing those exposures from causing adverse health outcomes. There is a growing need to understand national trends in exposures and health outcomes associated with climate change and the effectiveness of climate adaptation strategies for health. To date, most indicators for health implications of climate change have been designed as independent, individual metrics. This approach fails to take into account how exposure-outcome pathways for climate-attributable health outcomes involve multiple, interconnected components. We propose reframing climate change and health indicators as a linked system of indicators, which can be described as follows: upstream climate drivers affect environmental states, which then determine human exposures, which ultimately lead to health outcomes; these climate-related risks are modified by population vulnerabilities and adaptation strategies. We apply this new conceptual framework to three illustrative climate-sensitive health outcomes and
\end{abstract}

This article is part of the topical collection "National Indicators of Climate Changes, Impacts, and Vulnerability", edited by Melissa A. Kenney and Anthony C. Janetos.

John M. Balbus

john.balbus@nih.gov

1 Contractor, Office of the Director, National Institute of Environmental Health Sciences, Bethesda, MD, USA

2 Climate Program Office, National Oceanic and Atmospheric Administration, Silver Spring, MD, USA

3 Dean's Office, Office of Academic Affairs, Environmental Health Science, College of Public Health, University of Georgia, Athens, GA, USA

4 Office of the Director, National Institute of Environmental Health Sciences, Bethesda, MD, USA 
associated exposure-outcome pathways: pollen allergies and asthma, West Nile virus infection, and vibriosis.

Keywords Climate change $\cdot$ Health $\cdot$ Public health · Indicators · Indicator system · Framework

\section{Background}

Climate change poses one of the most significant challenges to human health around the world (Costello et al. 2009). Given this level of importance, as well as the inherent complexity of the interactions between climate change and health (Haines and Ebi 2019; Tong and Ebi 2019; Watts et al. 2018; Pachauri and Meyer 2014), there is an urgent need to monitor trends in climate change-related exposures and health outcomes. This in turn requires enhanced data collection for monitoring and surveillance (Watts et al. 2015) to build the evidence base for collective understanding of the causal links between climate change and health and to better support public health action and decision making.

Effective public health practice is built upon the collection and interpretation of data on health status, health hazards and their root causes, and community needs and assets (CDC 2020). Establishing baseline status, evaluating trends, and analyzing successes and failures of public health interventions require the development of useful, robust public health indicators. Indicators are signals of phenomena that often cannot be directly measured or seen (Briggs 2003). Indicators are summary measures that describe complex systems and track and communicate the state of such systems (English et al. 2009). They provide valuable longterm data to (1) guide prevention strategies, interventions, and health services; (2) evaluate public health policies; and (3) form the basis of health communications for disseminating information to stakeholders (English et al. 2009). The use of a consistent set of indicators allows for comparison of phenomena over time and across geographic scales.

Traditional environmental and health indicators have tended to be conceptualized and collected as independent metrics, uncoupled from other factors in the causal pathway and detached from risk modifiers (Ebi et al. 2018; McMichael 2013). For many environmental health effects, such as those related to asbestos or lead, the relationship between exposure and outcome is relatively direct and straightforward, so independent indicators are useful for understanding exposures and trends in outcomes. Climate change, in contrast, is a complex exposure, one of several determinants of downstream health effects, and thus a greater challenge in terms of assessing impacts on health outcomes (Xun et al. 2010; Ebi 2008; Wilkinson et al. 2003; Hess et al. n.d.). The 2016 Climate and Health Assessment published by the US Global Change Research Program (GCRP) describes this complexity through multistep exposure pathways that include contextual measures representing additional environmental, social, and behavioral determinants of health (Crimmins et al. 2016).

For a number of health outcomes, such as heat-related mortality, there is a high degree of attribution to a climate-related factor. Current surveillance systems capture most deaths for which heat exposure is identified as an underlying or contributing cause on the death certificate (Vaidyanathan et al. 2020), and there is a relatively robust evidence base for associations between climate change related factors like frequency of heat waves and health outcomes. For such health outcomes as heat, it should therefore be possible to create a more complete indicator system that includes causal factors, modifying factors, and trends in outcomes. For 
other health outcomes, such as asthma or many infectious diseases, the degree of attribution and even the precise climate-related causative factors may not be fully known, and the health outcomes may not be adequately captured by current surveillance systems. Collecting spatially and temporally relevant data along the causal chain, as well as modifiers, is critical to establish evidence of trends in climate and health outcomes, elucidate the climate-attributable portion of the association, and identify which demographic and societal factors modify the exposureoutcome pathway (Wilkinson et al. 2003). Nonetheless, it may be possible to identify some components in the causal pathway and begin to present indicators for these outcomes with more complex or uncertain causal pathways in a linked manner. While such a systematic approach to indicators may initially be incomplete or exploratory, it may then also help to identify knowledge and data gaps (Beard et al. 2016; Luber and McGeehin 2008; Haines et al. 2006; Rogers and Randolph 2006).

\subsection{Building on prior indicator efforts}

A number of federal agencies and national organizations independently produce collections of indicators relevant to climate change and health at the national level, including the Centers for Disease Control and Prevention (CDC), Environmental Protection Agency (EPA), National Oceanic and Atmospheric Administration (NOAA), and US Global Change Research Program (GCRP) (Table 1). CDC maintains a database of climate change and health indicators, primarily at the county scale, on their Environmental Public Health Tracking platform. Beyond climate-sensitive health outcomes, the platform features indicators for climate and environmental exposures and underlying vulnerabilities. In addition to collecting primary climate and environmental data that are used to develop indicators by other agencies such as CDC, NOAA maintains a small set of health-relevant indicators. EPA uses data collected by its own agency as well as external organizations to produce an inventory of climate and environmental indicators and a handful of health outcome indicators. GCRP hosts and manages a selection of indicators related to climate. The Council of State and Territorial Epidemiologists (CSTE) and the US Department of Agriculture (USDA) both have put forth recommendations for climate change indicators that are relevant for their discipline but have not created or collected indicators. In all cases, climate and health indicators are not presented as linked along causal pathways or combined with specific vulnerability factors or adaptation metrics.

Prior conceptual frameworks used to guide environmental assessments and sustainable development have grouped indicators with underlying causal connections (Table 2). The Driving Force-Pressure-State-Impact-Response (DPSIR) model builds on the original Pressure-State-Response (Rapport and Friend 1979; OECD 1993), introducing upstream driving forces that impose pressures on the environment and consequently change the state of the environment. These effects can lead to impacts on human health or ecosystems and shape societal responses that can in turn influence each link within the causal chain (EEA 1999). This framework has provided a useful systems-based approach to informing environmental indicator selection, but because it does not explicitly consider human exposures and is primarily focused on environmental impacts (Hambling et al. 2011; Niemeijer and de Groot 2008), it is not as applicable for climate change impacts on health.

The World Health Organization (WHO) conceptualized the Drivers-Pressures-State-Exposure- $E$ ffect-Action (DPSEEA) model as a way to guide indicator development and environmental policies that impact human health outcomes (Corvalán et al. 1999; Kjellström and Corvalán 1995). Similar to previous models, the DPSEEA shares the same upstream driving 
Table 1 Data repositories for climate or climate change and health indicators, which can include exposure, health, or adaptation indicators. Repositories may house indicators from other external agencies

Indicator repository

(agency and categorya)

\section{Component in framework ${ }^{b}$}

\begin{tabular}{llllll}
\hline CD & ES & PE & HO & PV & AS
\end{tabular}

CDC

Air quality

Asthma

Climate change (cross-cutting)

COPD

Drought

Heart disease

Heat stress illness

Populations and vulnerabilities/community characteristics

\section{EPA}

Ecosystems

Greenhouse gases

Health and society

Oceans

Snow and ice

Weather and climate

NOAA

Temperature, precipitation, and drought

Extremes

Societal impacts

Snow and ice

Teleconnections

USGCRP

$\begin{array}{cccc} & X & X & \\ & & & X \\ & X & X & X \\ & & X \\ & & \\ & & \\ & & \\ & & & X\end{array}$

X

$\begin{array}{llll}X & X & \\ X & & & \\ & & X & X \\ X & X & & \\ X & X & \\ X & X & \\ & & \\ X & X & \\ X & X & \\ & X & X \\ & X & \\ X & & \\ X & X & \end{array}$

CDC: Centers for Disease Control and Prevention

EPA: Environmental Protection Agency

NOAA: National Oceanic and Atmospheric Administration

USGCRP: US Global Change Research Program

$C D$ climate driver; $E S$ environmental state; $P E$ proximate exposure; $H O$ health outcome; $P V$ population vulnerability; $A S$ adaptation strategies

${ }^{a}$ Indicators are identified at the higher level category and may include multiple sub-categories of measures

${ }^{b}$ At least one of the measures in the category of indicators has relevance to human health exposure pathways

Table 2 Comparison of frameworks ${ }^{\text {a }}$. DPSIR Driving force-Pressure-State-Impact-Response; DPSEEA DriversPressures-State-Exposure-Effect-Action; MEME Multiple Exposures-Multiple Effects; NCIS National Climate Indicator System; ICCHIS Integrated Climate Change and Health Indicator System

Features of the Framework

Framework

DPSIR DPSEEA MEME NCIS ICCHIS

Adaptable for climate change impacts

Based on a causal framework

Describes upstream and downstream factors

Provides route of exposure

Includes interventions or adaptations

Incorporates sociodemographic vulnerabilities along the causal

$\begin{array}{lllll} & X & X & X & X \\ X & X & X & & \text { X } \\ X & X & & X & \text { X } \\ & X & X & & \text { X } \\ \text { X } & \text { X } & \text { X } & \text { X } & \text { X } \\ & & & & \text { X }\end{array}$

chain

a Adapted from Hambling et al. 2011

\section{Springer}


forces, pressures, and state concepts. Differences appear subsequent to these steps that emphasize human exposures: changes in environmental state can generate exposures to environmental hazards that lead to health effects, and across the entire framework, actions can be implemented to influence each step.

In discussing frameworks for indicators of children's environmental health, Briggs noted the DPSEEA framework posed a risk of simplifying causal chains into single linear pathways and proposed instead that the Multiple Exposures-Multiple Effects (MEME) framework might be more suitable for complex systems (Briggs 2003). Notably, the MEME framework explicitly incorporates contexts that can include socioeconomic and demographic vulnerability factors as well as preventive and remedial actions, which map well to climate mitigation and adaptation. However, there is an overall lack of distinction between upstream and downstream elements.

Hambling et al. reviewed eleven frameworks that could be applied to climate change and health indicators, including the DPSIR, DPSEEA, and MEME frameworks (Hambling et al. 2011). They considered the DPSEEA framework as providing the best starting point for an integrated system of indicators for climate change and health, noting that by explicitly acknowledging the linkages among ecological and environmental states and human health, it is possible to direct interventions early in the causal chain to not only protect human health, but also in some cases, to preserve ecological integrity. In fact, around 2001, the WHO put forth the idea of adapting the DPSEEA conceptual framework to climate change and human health (Füssel and Klein 2004). More recently, the DPSEEA framework has been adapted for climate change and health issues, such as in New South Wales, Australia, to guide appropriate public health actions (Boylan et al. 2018). Challenges with the DPSEEA framework include incorporating non-climate factors into the causal chain and characterizing causal pathways with multiple sequential ecological steps (Füssel and Klein 2004).

Although not explicitly framed around causal relationships, the concept of a National Climate Indicator System was introduced in 2016 with climate change as a focal point and represented as a "system of physical, natural, and societal indicators that communicate and inform decisions about key aspects of the physical climate, climate impacts, vulnerabilities, and preparedness" (Kenney et al. 2016). Kenney et al. later proposed a framework and rationale for a system of national climate indicators to provide a mechanism for sustained climate assessment (Kenney et al. 2018). Within this framework, health is conceptualized as a central factor influenced by climate and ecosystem drivers as well as adaptation strategies. While the authors do not identify any specific indicators, they list categories of health indicators that align closely with the exposure pathways used in this paper, including population vulnerability indicators, and also recommend expanding existing indicator systems with indicators of responses. They, however, do not propose groups of linked indicators to represent each exposure-outcome pathway.

\section{The conceptual framework}

\subsection{Introduction}

In order to create a comprehensive, integrated indicator system that captures not only the critical components of causal pathways but also quantifiable metrics of vulnerability and adaptation responses, we propose a new conceptual framework for a national Integrated Climate Change and Health Indicator System (Fig. 1). This system of impact indicators 


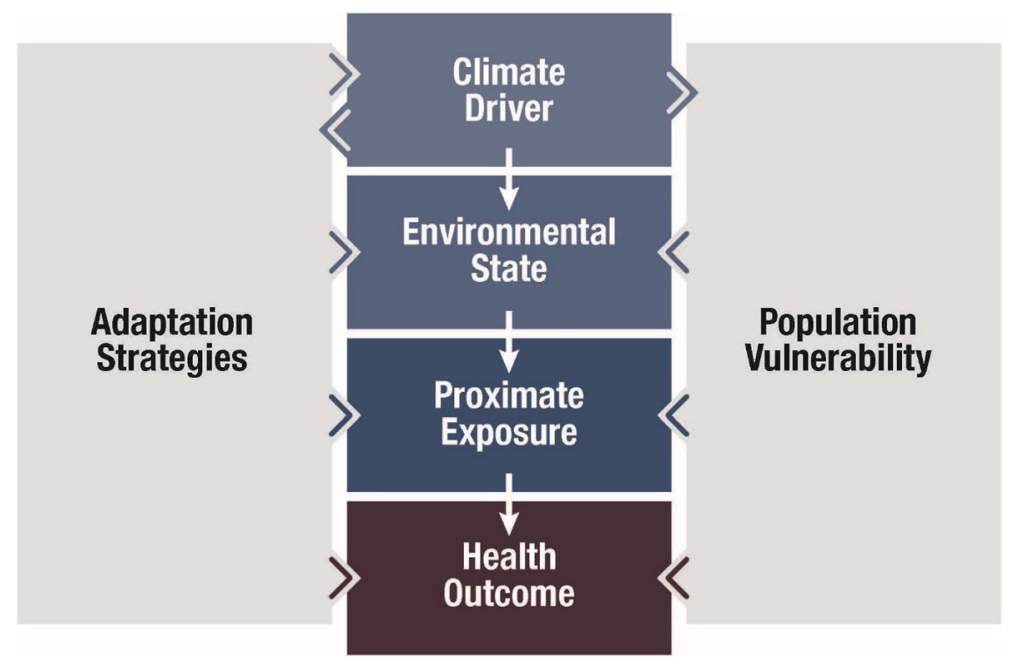

Fig. 1 Conceptual diagram of the Integrated Climate Change and Health Indicator System Framework

combines elements of the DPSEEA and MEME frameworks, placing multi-step causal chains associated with climate change within a context of socioeconomic and demographic factors, societal actions, and other non-climate drivers. The components of our indicator system align closely with the exposure pathways concept of the 2016 GCRP Climate and Health Assessment (Crimmins et al. 2016) but add consideration of societal actions related to adaptation that were deliberately excluded from the framing of the report. While there are other important relationships between climate change and health, such as the health benefits of certain climate change mitigation actions, the framework presented in this paper focuses on capturing trends important to the health impacts of climate change and efforts to ameliorate those impacts.

For the purposes of our proposed indicator system, climate drivers include the climatological and meteorological conditions that cause downstream environmental and ecosystem changes. Environmental states refer to the status of the environment or ecosystem created influenced by upstream climatological and meteorological factors. Proximate exposures include environmental and biological factors that, when humans come in contact with them, affect human health by directly causing disease or injury. Health outcomes are illnesses or injuries resulting from such contact with biological, physical, or chemical substances in the environment. Population vulnerabilities encompass socioeconomic or demographic factors that render populations susceptible to health effects from climate change. Adaptation strategies are the actions developed or implemented to improve outcomes in response to the adverse effects of climate change and can reflect aspects of community resilience.

One goal of applying this systems approach to developing climate change and health indicators is to facilitate a "virtuous circle" of science whereby integration of exposure-outcome pathways, vulnerability factors, and societal responses leads to the following: (1) early identification of gaps in either scientific understanding of linkages or collection of data that are relevant to proposed linkages; (2) development of indicators of human health vulnerability that are most relevant to specific pathways; (3) association of societal responses with specific exposure pathways, and therefore specific environmental states and health outcomes, by which to measure the effectiveness of those societal responses; and (4) evaluation of gaps and trends that informs ongoing research in an iterative manner. We propose that integrating related factors in this way will lead to 
more relevant and accurate understanding of what is working well, what is not working, and the extent to which existing efforts to manage health risks are robust and effective. This systems approach will help to identify the most critical data for sustained observation and surveillance in order to track climate change impacts on human health in the USA.

\subsection{Selection of exposure-outcome pathways}

An initial question to consider is which exposure-outcome pathways should be included in a national set of climate and human health indicators. We propose as a starting point including exposure-outcome pathways for the major health outcomes mentioned in the 2016 GCRP Climate and Health Assessment and the Fourth National Climate Assessment (Crimmins et al. 2016; Reidmiller et al. 2018). Taken from the Climate and Health Assessment Executive Summary, Fig. 2 provides a useful basis for identifying some of the potential indicators along the causal pathways for the seven different pathways listed. Some of the exposure-outcome pathways are categories, like water-borne and vector-borne diseases, that may have several important sub-pathways not included in the figure. For example, while Fig. 2 identifies Lyme disease as an important vector-borne disease, it does not include other important vector-borne diseases in the USA such as West Nile virus (WNV) infection.

\subsection{Selection of indicators}

Previous authors have identified selection criteria for environmental health indicators (Hambling et al. 2011; Briggs 2003). For our framework, we use as a starting point the selection criteria highlighted by Briggs, which fall into two categories: scientific validity and utility/ practicability (Briggs 2003). In the absence of easy quantification of selection criteria, expert judgment is often used to score, rank, and weigh the various criteria. Initial sets of indicators for each exposure pathway can be adapted from the discussion of climate linkages in major assessments and reports, including those from the GCRP (Reidmiller et al. 2018; Crimmins et al. 2016) and Intergovernmental Panel on Climate Change (Pachauri and Meyer 2014).

The complex exposure-outcome pathways involved in the health impacts of climate change complicate the process of selecting the most appropriate indicators. Specific climate drivers for a given exposure pathway may vary in time and space. For example, the literature suggests that for South Dakota, relative humidity and precipitation variations are key predictors of high-risk areas for WNV, while for coastal California, warmer temperatures are critical predictors of transmission risk (Skaff et al. 2020; Hess et al. 2018). Moreover, the factors most important for predicting variations in risk over finer time and space scales, for example, predicting high-risk counties in a state over a time period of weeks, may not be the most relevant for assessing longer term trends in infectious disease risk related to climate change (Hess et al. 2018). As a consequence, tradeoffs among selection criteria are necessary. Indicators most useful for understanding and communicating national-scale trends may not be the same factors that are useful for predicting disease risk on a time and spatial scale relevant to public health interventions. Similarly, given the many potential ways to process primary meteorological observations to develop critical climate driver measures, it is likely that ongoing research may identify similar but slightly different specific drivers for the various exposure pathways. In designing a national system of indicators for a comprehensive set of exposure pathways, there are likely to be tradeoffs between specificity and optimal scientific validity of upstream drivers and the criteria of practicality, understandability, and parsimony. 


\begin{tabular}{|c|c|c|c|c|}
\hline & $\begin{array}{l}\text { Climate } \\
\text { Driver }\end{array}$ & Exposure & $\begin{array}{l}\text { Health } \\
\text { Outcome }\end{array}$ & Impact \\
\hline $\begin{array}{c}\text { Extreme } \\
\text { Heat }\end{array}$ & $\begin{array}{l}\text { More frequent, } \\
\text { severe, prolonged } \\
\text { heat events }\end{array}$ & $\begin{array}{l}\text { Elevated } \\
\text { temperatures }\end{array}$ & $\begin{array}{l}\text { Heat-related death } \\
\text { and illness }\end{array}$ & $\begin{array}{l}\text { Rising temperatures will lead to an } \\
\text { increase in heat-related deaths } \\
\text { and illnesses. }\end{array}$ \\
\hline $\begin{array}{l}\text { Oొ } \\
\text { Outdoor } \\
\text { Air Quality }\end{array}$ & $\begin{array}{l}\text { Increasing } \\
\text { temperatures } \\
\text { and changing } \\
\text { precipitation } \\
\text { patterns }\end{array}$ & $\begin{array}{l}\text { Worsened air quality } \\
\text { (ozone, particulate } \\
\text { matter, and } \\
\text { higher pollen } \\
\text { counts) }\end{array}$ & $\begin{array}{l}\text { Premature death, } \\
\text { acute and chronic } \\
\text { cardiovascular and } \\
\text { respiratory illnesses }\end{array}$ & $\begin{array}{l}\text { Rising temperatures and wildfires } \\
\text { and decreasing precipitation will } \\
\text { lead to increases in ozone and } \\
\text { particulate matter, elevating the } \\
\text { risks of cardiovascular and } \\
\text { respiratory illnesses and death. }\end{array}$ \\
\hline Flooding & $\begin{array}{l}\text { Rising sea level and } \\
\text { more frequent or } \\
\text { intense extreme } \\
\text { precipitation, } \\
\text { hurricanes, and } \\
\text { storm surge events }\end{array}$ & $\begin{array}{l}\text { Contaminated water, } \\
\text { debris, and disruptions } \\
\text { to essential } \\
\text { infrastructure }\end{array}$ & $\begin{array}{l}\text { Drowning, injuries, } \\
\text { mental health } \\
\text { consequences, } \\
\text { gastrointestinal and } \\
\text { other illness }\end{array}$ & $\begin{array}{l}\text { Increased coastal and inland } \\
\text { flooding exposes populations to a } \\
\text { range of negative health impacts } \\
\text { before, during, and after events. }\end{array}$ \\
\hline $\begin{array}{c}\text { Vector-Borne } \\
\text { Infection } \\
\text { (Lyme Disease) }\end{array}$ & $\begin{array}{l}\text { Changes in } \\
\text { temperature } \\
\text { extremes and } \\
\text { seasonal weather } \\
\text { patterns }\end{array}$ & $\begin{array}{c}\text { Earlier and } \\
\text { geographically } \\
\text { expanded tick activity }\end{array}$ & Lyme disease & $\begin{array}{l}\text { Ticks will show earlier seasonal } \\
\text { activity and a generally northward } \\
\text { range expansion, increasing risk } \\
\text { of human exposure to Lyme } \\
\text { disease-causing bacteria. }\end{array}$ \\
\hline $\begin{array}{l}\text { Water-Related } \\
\text { Infection } \\
\text { (Vibrio vulnificus) }\end{array}$ & $\begin{array}{l}\text { Rising sea surface } \\
\text { temperature, } \\
\text { changes in precipi- } \\
\text { tation and runoff } \\
\text { affecting coastal } \\
\text { salinity }\end{array}$ & $\begin{array}{l}\text { Recreational } \\
\text { water or shellfish } \\
\text { contaminated with } \\
\text { Vibrio vulnificus }\end{array}$ & $\begin{array}{l}\text { Vibrio vulnificus } \\
\text { induced diarrhea } \\
\text { \& intestinal illness, } \\
\text { wound and blood- } \\
\text { stream infections, } \\
\text { death }\end{array}$ & $\begin{array}{l}\text { Increases in water temperatures } \\
\text { will alter timing and location of } \\
\text { Vibrio vulnificus growth, increas- } \\
\text { ing exposure and risk of water- } \\
\text { borne illness. }\end{array}$ \\
\hline $\begin{array}{l}\text { Food-Related } \\
\text { Infection } \\
\text { (Salmonella) }\end{array}$ & $\begin{array}{l}\text { Increases in } \\
\text { temperature, } \\
\text { humidity, and } \\
\text { season length }\end{array}$ & $\begin{array}{l}\text { Increased growth } \\
\text { of pathogens, } \\
\text { seasonal shifts in } \\
\text { incidence of } \\
\text { Salmonella } \\
\text { exposure }\end{array}$ & $\begin{array}{l}\text { Salmonella } \\
\text { infection, } \\
\text { gastrointestinal } \\
\text { outbreaks }\end{array}$ & $\begin{array}{l}\text { Rising temperatures increase } \\
\text { Salmonella prevalence in food; } \\
\text { longer seasons and warming } \\
\text { winters increase risk of exposure } \\
\text { and infection. }\end{array}$ \\
\hline $\begin{array}{l}\text { Mental Health } \\
\text { and Well-Being }\end{array}$ & $\begin{array}{l}\text { Climate change } \\
\text { impacts, especially } \\
\text { extreme weather }\end{array}$ & $\begin{array}{l}\text { Level of exposure } \\
\text { to traumatic events, } \\
\text { like disasters }\end{array}$ & $\begin{array}{l}\text { Distress, grief, } \\
\text { behavioral health } \\
\text { disorders, social } \\
\text { impacts, resilience }\end{array}$ & $\begin{array}{l}\text { Changes in exposure to climate- } \\
\text { or weather-related disasters } \\
\text { cause or exacerbate stress and } \\
\text { mental health consequences, } \\
\text { with greater risk for certain } \\
\text { populations. }\end{array}$ \\
\hline
\end{tabular}

Fig. 2 Exposure pathways diagram illustrating examples of climate impacts on human health from the 2016 U.S. Global Change Research Program Climate and Health Assessment

\section{The indicator system framework: three examples}

We present the application of the conceptual framework to three distinct climate-related health outcomes, allergies related to pollen, West Nile virus (WNV) infections, and Vibrio sp. infections as illustrative examples of how this conceptual framework may be used in practice. Primarily using indicators that are currently available from federal agencies, we identify indicators for these three exposure-outcome pathways that could comprise the elements of an Integrated Climate Change and Health Indicator System Framework. These examples are 
for descriptive purposes only; an actual initial set of pilot indicators would be selected through a more robust and inclusive process.

\subsection{Allergies and other respiratory conditions}

Allergies and other respiratory conditions related to pollen have been associated with changes in climate (Barnes 2018). Warming temperatures, shifts in precipitation, and increasing concentrations of carbon dioxide affect plant growth and phenology (Ziska et al. 2019; Katelaris and Beggs 2018; Anenberg et al. 2017; Behrendt and Ring 2012). The pathway of data from exposure to outcome begins with the main (a) climate drivers of increasing surface temperatures, shifts in precipitation, and rising carbon dioxide levels, which shape various (b) environmental states, including earlier flowering and longer pollen seasons. These changing environmental states in turn affect the magnitude and frequency of (c) proximate exposures, such as the quantity and species of pollen grains in the air, which impact (d) human health through allergic disease or by exacerbating existing respiratory conditions like asthma (Katelaris and Beggs 2018); (e) population vulnerabilities such as age and existing morbidities and (f) adaptation strategies such as enhanced environmental monitoring (Katelaris and Beggs 2018) implemented at the local or more macro level play a role in modifying the linkage between exposure and outcome.

\subsubsection{Potential initial indicator set}

Climate drivers: $\mathrm{CO}_{2}$ concentration; national average surface temperature (wintertime) Environmental state: first day of flowering in selected regions

Proximate exposures: peak oak pollen counts in selected regions; oak pollen season length

Health outcomes: asthma mortality; asthma and allergic disease-related hospitalizations; asthma and allergic disease-related emergency room visits

Vulnerability factor: pre-existing conditions

Adaptation strategy: early warning/pollen surveillance systems

\subsection{West Nile virus infection}

As a vector-borne disease, WNV infection is sensitive to climate and weather factors. Climate change affects both spatial and temporal patterns in human WNV cases because the transmission cycle involves stages of mosquito development and bird migration patterns that are vulnerable to climate and environment factors (Beard et al. 2016). These factors also influence human behavior outdoors, which influences the likelihood of exposure and infection. A linked indicator system can help associate upstream climate factors and downstream health outcomes and capture at least some of the critical variables and mechanics involved in WNV disease transmission. Starting from the main (a) climate drivers of precipitation levels and increasing surface temperatures, the pathway continues to the (b) environmental states, areas of standing water and birds infected with the virus, that are generated by these driving forces (Paull et al. 2017; Paz 2015; Paz and Semenza 2013). These environments create amenable habitats for downstream (c) proximate exposures like the vector index of infected mosquitoes, which in 
turn infect both bird populations and humans, causing the ultimate (d) health outcome, WNV infection, in individuals (Paz and Semenza 2013). In addition to climate and environmental factors, certain (e) population vulnerabilities, including age and outdoor occupation, and (f) adaptation strategies such as vector control programs and public health communication campaigns act within the system to modify WNV exposure and infection in the population.

\subsubsection{Potential initial indicator set}

Climate drivers: national average surface temperature (wintertime); soil moisture anomalies; precipitation anomalies

Environmental states: satellite-derived images of standing water; anomalies from 30year average

Proximate exposures: Culex mosquito counts; infected sentinel animals; date of first sentinel animal infection; annual prevalence of WNV disease in mosquitoes; annual prevalence of $W N V$ disease in sentinel species

Health outcome: WNV neuroinvasive disease cases

Vulnerability factors: population over 65; percentage outdoor worker

Adaptation strategy: integrated pest management strategy

\subsection{Vibriosis}

Changes in climate have been shown to affect the distribution and proliferation of bacteria causing vibriosis (i.e., Vibrio and related groups) and cholera (Vibrio cholerae) in humans (Semenza et al. 2012; Vezzulli et al. 2013; Vezzulli et al. 2016). The main (a) climate drivers include rising sea surface temperatures for Vibrio exposures and infection and, in the case of cholera, heavy precipitation, which could include extreme weather events. These factors affect the (b) environmental state of the pathogen, leading to variations in concentrations of Vibrio bacteria, including potentially virulent subpopulations (Ebi et al. 2017; Semenza et al. 2012; Vezzulli et al. 2013). People are (c) exposed to these pathogens through ingestion when they consume raw or undercooked seafood containing high levels of these bacteria, via dermal contact through wounds or broken skin, or through eye and ear contact with contaminated water during recreational activities. This contact increases the risk of exposure and adverse (d) health outcomes such as vibriosis resulting in gastrointestinal illness, dermal infections, or eye and ear infections, conditions that may be modified by (e) population vulnerabilities including age and the presence of underlying chronic disease conditions in infected individuals; (f) an adaptation strategy such as monitoring of the seafood supply could also modulate risk (Tacket et al. 1984).

\subsubsection{Potential initial indicator set}

Climate drivers: national average surface temperature; sea surface temperature; extreme precipitation 
Environmental states: sea surface temperature anomalies; sea surface temperatures exceeding minimum thresholds $\left(15^{\circ} \mathrm{C}\right)$; duration at temperatures above $15^{\circ} \mathrm{C}$

Proximate exposure: Vibrio concentrations in selected sentinel estuaries

Health outcome: Vibrio illnesses

Vulnerability factors: age (over 50 and under 15); gender (male); immune status; liver conditions

Adaptation strategy: Vibrio early warning systems

\section{Discussion}

This framework for a national Integrated Climate Change and Health Indicator System is intended to advance the understanding of trends in the human health impacts of climate change, inform data collection and surveillance strategies, and guide, as well as evaluate, public health actions. Over the long run, the development and refinement of indicator systems will benefit a number of audiences. First and foremost, the general public and policymakers will have greater understanding of the importance of health as an area of climate change impacts. Public health professionals will have a more robust foundation for data-driven guidelines and policies related to climate change and human health. Researchers will have a clearer sense of knowledge gaps. And data stewards will have greater support for maintenance and expansion of specific earth observation parameters and health surveillance data for public health purposes.

By establishing a linked system of indicators based on current understanding of exposure pathways and linkages, the framework provides a structured template within which to expand our collective understanding of climate change and its impacts on human health. While health outcome indicators may change over time from a wide variety of factors, consideration of linked indicators along causal pathways aids in the interpretation of health trends in the context of potential influences of climate change and secondary environmental changes. As additional data and research results are incorporated, the system can be refined and modified to reflect up-to-date knowledge. For example, the relationships between phenology and asthma exacerbations are just being explored in the USA (Sapkota et al. 2020). Whereas prior indicators focused on pollen season length, the finding that both late and early onsets of phenologic spring are associated with increased asthma hospitalizations would suggest that an indicator of anomalies of phenology, and not just earlier onset, would be important to include. Moreover, while remotely sensed phenology provides a proxy of pollen concentrations in the absence of a national pollen monitoring network, advances in automated pollen sampling using drones may lead to the ability to incorporate more precise exposure measures over time. In this example, as in all cases, a balance will need to be struck between revisions in the face of scientific advances and the need for continuous, unchanging indicator definitions in order to delineate trends over time. For an area of science as critical and yet relatively immature as climate change and human health, identifying some sets of indicators as clearly developmental or as pilots could help to strike this balance.

The complex nature of indicator systems necessitates the involvement of experts across multiple disciplines, from climate scientists and meteorological specialists, to biologists and infectious disease experts, to epidemiologists and public health practitioners. Because the Integrated Climate Change and Health Indicator System Framework attempts to capture the connections linking climate drivers to environmental states to proximate exposures and eventual health outcomes, as well as population vulnerabilities and adaptation strategies, relevant data sets are required for all these components. Consequently, coordination is key 
across earth observation systems and biological and health surveillance systems. Specialists in their respective fields are needed to provide their expertise to identify the most appropriate data sets, interpret the data and uncertainties, evaluate existing or create new indicators, and establish linkages throughout the exposure-outcome pathways. For some pathways, such as those for vector-borne diseases, ongoing research may reveal that the heterogeneity of ecosystems and primary drivers of disease risk around the country preclude national-scale linked indicators. In such cases, national scale modeling of vector range and niches may be the best proxy available. It may still be useful for local public health departments to track more localized, smaller-scale indicators of risk drivers of vector-borne diseases to guide their own efforts. Organizations that fund or provide services related to earth observing systems, biological monitoring system, and health surveillance systems should find that an integrated framework such as proposed in this paper provides enhanced guidance and justification for their missions.

Applying this framework will require a combination of vetting existing indicators, developing new indicators from existing datasets, and, in some cases, awaiting or promoting the collection of new data. For example, CDC currently hosts datasets containing climate-sensitive disease incidence and prevalence at the county level (CDC 2021). It would be relatively straightforward to aggregate a national scale indicator from the county-level data for these diseases. Other types of indicators, such as trends in infectious disease vectors or various types of pollen concentrations do not currently have robust sustained datasets to support them and would require more development of the monitoring data.

Building a national system of indicators presents an additional, particularly challenging scenario. Variation in the scope and scale of data (e.g., climate data on a kilometer grid at a daily timescale but health data available at the county level on a monthly timescale) may make it difficult to connect indicators. The current landscape of the health system is fragmented across the federal, state, local, and Tribal levels, which complicates data collection, validation of health outcomes of interest, and linkage of health data at the appropriate temporal and spatial levels to earth observation data. Identifying the appropriate temporal and geospatial scales for the indicator system will depend on the specific exposure-outcome pathway. In some cases, such as waterborne or vector-borne diseases that are more influenced by regional conditions, indicators may need to be presented as collections of localized data; in others, such as extreme heat-related illnesses, national summative measures may be suitable.

Taking a systems approach to climate change and human health indicators should facilitate more effective public health practice and more actionable public communications. By combining a comprehensive, multi-step model of exposure-outcome pathways with metrics of population vulnerability and societal interventions, a more complete picture of current risk levels and trends over time can emerge. This allows assessment of health status in a more robust risk context and helps identify the most salient driving forces and opportunities for refinements in public health protection. At the same time, organizing indicators as a holistic, multifactorial system instead of as individual indicators is a novel concept and may present challenges in communicating information. Thus, significant attention needs to be paid not only to the scientific evidence supporting linking indicators in this way but also to the communication science and development of useful messages to describe the indicators from a systems perspective.

Transitioning from indicators as individual metrics to interconnected systems may present some unique logistical challenges. Initiating and sustaining partnerships may be difficult because there may be competing agency priorities across the institutions that are collecting data and generating indicators. Such discrepancies in priorities could hinder the process of 
merging data streams for an indicator system, providing data updates, or even coordinating collaborative activities. Tracking climate change indicators as a system can be a resourceintensive approach, and there might be limitations in terms of time, personnel, and money for sustained efforts. Privacy concerns related to health data and data security are not unique to an indicator systems framework. The issue, however, is further complicated within this context because of the multi-disciplinary nature inherent to a system of indicators. Data stewards of health-related indicators have established security protocols for safeguarding their data inventories, but the question of where and how to securely maintain a repository of indicators developed from health and non-health data is more complex.

\section{Conclusion}

Climate change has direct and indirect impacts on population health, and indicator systems are useful for capturing the complex relationships among upstream climate and downstream health effects while incorporating potential modifying vulnerabilities and adaptation strategies. This proposed Integrated Climate Change and Health Indicator System Framework provides a structure to try to capture the complex dynamics that define a climate-attributable health outcome. This paradigm shift in developing and tracking climate change and human health indicators as a linked system necessitates the collaboration of subject matter experts from multiple disciplines in collecting data, managing inventories of data sets, creating indicators, and monitoring trends. Tracking indicators as part of an integrated system for different climate-sensitive health outcomes has the potential to generate useful data to inform policymakers. The power comes from the comprehensive assessment across the indicator data streams which can then more usefully inform decision makers about trends, projections, and effectiveness of interventions. In addition, this proposed framework helps to identify the most essential earth observations and surveillance data for both continuous monitoring and ongoing research. Scientists working on these indicator systems also benefit from the iterative process of refining data inputs or adding or eliminating indicator components as research uncovers new information. Advancing the concept of indicators from individual, independent measures to an inter-connected system of upstream, downstream, and modifying indicators enhances the current state of thinking by bringing a holistic perspective to the approach of developing climate change and health indicators.

Acknowledgments The authors thank Paul Schramm (CDC) for his invaluable comments and suggestions on the manuscript.

Availability of data and material Not applicable.

Code availability Not applicable.

Authors' contributions Ann Liu and John Balbus wrote the manuscript; Juli Trtanj, Erin Lipp, and John Balbus conceptualized the framework and reviewed and edited the manuscript.

\section{Declarations}

This work was supported, in part, by the NIH, National Institute of Environmental Health Sciences. 
Conflict of interest The authors declare that there is no conflict of interest.

Open Access This article is licensed under a Creative Commons Attribution 4.0 International License, which permits use, sharing, adaptation, distribution and reproduction in any medium or format, as long as you give appropriate credit to the original author(s) and the source, provide a link to the Creative Commons licence, and indicate if changes were made. The images or other third party material in this article are included in the article's Creative Commons licence, unless indicated otherwise in a credit line to the material. If material is not included in the article's Creative Commons licence and your intended use is not permitted by statutory regulation or exceeds the permitted use, you will need to obtain permission directly from the copyright holder. To view a copy of this licence, visit http://creativecommons.org/licenses/by/4.0/.

\section{References}

Anenberg SC, Weinberger KR, Roman H, Neumann JE, Crimmins A, Fann N, Martinich J, Kinney PL (2017) Impacts of oak pollen on allergic asthma in the United States and potential influence of future climate change. GeoHealth 1:80-92

Barnes CS (2018) Impact of climate change on pollen and respiratory disease. Curr Allergy Asthma Rep 18:59

Beard CB, Eisen RJ, Barker CM, Garofalo JF, Hahn M, Hayden M, Monaghan AJ, Ogden NH, Schramm PJ (2016) Ch. 5: Vectorborne diseases. The impacts of climate change on human health in the United States: a scientific assessment. In: Edited by U.S. global change research program. Washington, DC, pp 129-156

Behrendt H, Ring J (2012) Climate change, environment and allergy. Chem Immunol Allergy 96:7-14

Boylan S, Beyer K, Schlosberg D, Mortimer A, Hime N, Scalley B, Alders R, Corvalan C, Capon A (2018) A conceptual framework for climate change, health and wellbeing in NSW, Australia. Public Health Res Pract 28

Briggs D (2003) Making a difference: indicators to improve children's environmental health. In, France

CDC. 2020. '10 Essential Public Health Services', CDC, https://www.cdc.gov/publichealthgateway/ publichealthservices/essentialhealthservices.html. Accessed 3 Nov 2020

CDC. 2021. 'National Environmental Public Health Tracking Network'. https://ephtracking.cdc.gov/ DataExplorer/. Accessed 13 April 2021

Corvalán CF, Kjellström T, Smith KR (1999) Health, environment and sustainable development: identifying links and indicators to promote action. Epidemiology 10:656-660

Costello A, Abbas M, Allen A, Ball S, Bell S, Bellamy R, Friel S, Groce N, Johnson A, Kett M, Lee M, Levy C, Maslin M, McCoy D, McGuire B, Montgomery H, Napier D, Pagel C, Patel J, de Oliveira JA, Redclift N, Rees H, Rogger D, Scott J, Stephenson J, Twigg J, Wolff J, Patterson C (2009) Managing the health effects of climate change: Lancet and University College London Institute for Global Health Commission. Lancet 373:1693-1733

Crimmins A, Balbus J, Gamble L, Beard CB, Bell JE, Dodgen D, Eisen RJ, Fann N, Hawkins MD, Herring SC, Jantarasami L, Mills DM, Saha S, Sarofim MC, Trtanj J, Ziska L (2016) The impacts of climate change on human health in the United States: a scientific assessment. In: In, edited by USGCRP. D.C, Washington

Ebi KL (2008) Healthy people 2100: modeling population health impacts of climate change. Clim Chang $88: 5-19$

Ebi KL, Ogden NH, Semenza JC, Woodward A (2017) Detecting and attributing health burdens to climate change. Environ Health Perspect 125:085004

Ebi KL, Boyer C, Bowen KJ, Frumkin H, Hess J (2018) Monitoring and evaluation indicators for climate change-related health impacts, risks, adaptation, and resilience. Int J Environ Res Public Health 15:1943

EEA (1999) "Environmental indicators: typology and overview." In, edited by European Environment Agency. Copenhagen

English PB, Sinclair AH, Ross Z, Anderson H, Boothe V, Davis C, Ebi K, Kagey B, Malecki K, Shultz R, Simms E (2009) Environmental health indicators of climate change for the United States: findings from the State Environmental Health Indicator Collaborative. Environ Health Perspect 117:1673-1681

Füssel HM, Klein R (2004) Conceptual frameworks of adaptation to climate change and their applicability to human health

Haines A, Ebi K (2019) The imperative for climate action to protect health. N Engl J Med 380:263-273

Haines A, Kovats RS, Campbell-Lendrum D, Corvalan C (2006) Climate change and human health: impacts, vulnerability, and mitigation. Lancet 367:2101-2109 
Hambling T, Weinstein P, Slaney D (2011) A review of frameworks for developing environmental health indicators for climate change and health. Int J Environ Res Public Health 8:2854-2875

Hess A, Davis JK, Wimberly MC (2018) Identifying environmental risk factors and mapping the distribution of West Nile virus in an endemic region of North America. GeoHealth 2:395-409

Hess JJ, Saha S, Schramm PJ, Conlon KC, Uejio CK, Luber GL (n.d.) "Projecting climate-related disease burden: a guide for health departments." In, edited by Centers for Disease Control and Prevention. Atlanta, GA

Katelaris CH, Beggs PJ (2018) Climate change: allergens and allergic diseases. Intern Med J 48:129-134

Kenney MA, Janetos AC, Lough GC (2016) Building an integrated U.S. National Climate Indicators System. Clim Chang 135:85-96

Kenney MA, Janetos AC, Gerst MD (2018) 'A framework for national climate indicators', Climatic Change

Kjellström T, Corvalán C (1995) Framework for the development of environmental health indicators. World Health Stat Q 48:144-154

Luber G, McGeehin M (2008) Climate change and extreme heat events. Am J Prev Med 35:429-435

McMichael AJ (2013) Globalization, climate change, and human health. N Engl J Med 368:1335-1343

Niemeijer D, de Groot RS (2008) A conceptual framework for selecting environmental indicator sets. Ecol Indic $8: 14-25$

OECD (1993) "OECD Core set of indicators for environmental performance review." In. Paris, France: OECD

Pachauri RK, Meyer L (2014) “Climate change 2014: Synthesis Report. Contribution of Working Groups I, II and III to the Fifth Assessment Report of the Intergovernmental Panel on Climate Change.” In, 151. Geneva, Switzerland: IPCC

Paull SH, Horton DE, Ashfaq M, Rastogi D, Kramer LD, Diffenbaugh NS, Kilpatrick AM (2017) Drought and immunity determine the intensity of West Nile virus epidemics and climate change impacts. Proc Biol Sci 284

Paz S (2015) Climate change impacts on West Nile virus transmission in a global context. Philos Trans R Soc Lond B Biol Sci 370:20130561

Paz S, Semenza JC (2013) Environmental drivers of West Nile fever epidemiology in Europe and Western Asiaa review. Int J Environ Res Public Health 10:3543-3562

Rapport D, Friend A (1979) "Towards a comprehensive framework for environmental statistics: a stress-response approach.” In, edited by Office of the Senior Adviser on Integration Statistics Canada. Ottowa, Canada

Reidmiller DR, Avery CW, Easterling DR, Kunkel KE, Lewis KLM, Maycock TK, Stewart BC (2018 “Impacts, risks, and adaptation in the United States: Fourth National Climate Assessment, Volume II.” In, edited by USGCRP. Washington, D.C

Rogers DJ, Randolph SE (2006) Climate Change and Vector-Borne Diseases. In: Hay SI, Graham A, Rogers DJ (eds) Advances in Parasitology. Academic Press

Sapkota A, Dong Y, Li L, Asrar G, Zhou Y, Li X, Coates F, Spanier AJ, Matz J, Bielory L, Breitenother AG, Mitchell C, Jiang C (2020) Association between changes in timing of spring onset and asthma hospitalization in Maryland. JAMA Netw Open 3:e207551-e207e51

Semenza JC, Herbst S, Rechenburg A, Suk JE, Höser C, Schreiber C, Kistemann T (2012) Climate change impact assessment of food- and waterborne diseases. Crit Rev Environ Sci Technol 42:857-890

Skaff NK, Cheng Q, Clemesha RES, Collender PA, Gershunov A, Head JR, Hoover CM, Lettenmaier DP, Rohr JR, Snyder RE, Remais JV (2020) Thermal thresholds heighten sensitivity of West Nile virus transmission to changing temperatures in coastal California. Proc Biol Sci 287:20201065

Tacket CO, Brenner F, Blake PA (1984) Clinical features and an epidemiological study of Vibrio vulnificus infections. J Infect Dis 149:558-561

Tong S, Ebi K (2019) Preventing and mitigating health risks of climate change. Environ Res 174:9-13

Vaidyanathan A, Malilay J, Schramm P, Saha S (2020) Heat-related deaths - United States, 2004-2018', MMWR. Morb Mortal Wkly Rep 69:729-734

Vezzulli L, Colwell RR, Pruzzo C (2013) Ocean warming and spread of pathogenic vibrios in the aquatic environment. Microb Ecol 65:817-825

Vezzulli L, Grande C, Reid PC, Hélaouët P, Edwards M, Höfle MG, Brettar I, Colwell RR, Pruzzo C (2016) Climate influence on Vibrio and associated human diseases during the past half-century in the coastal North Atlantic. Proc Natl Acad Sci U S A 113:E5062-E5071

Watts N, Neil Adger W, Agnolucci P, Blackstock J, Byass P, Cai W, Chaytor S, Colbourn T, Collins M, Cooper A, Cox PM, Depledge J, Drummond P, Ekins P, Galaz V, Grace D, Graham H, Grubb M, Haines A, Hamilton I, Hunter A, Jiang X, Li M, Kelman I, Lu L, Lott M, Lowe R, Luo Y, Mace G, Maslin M, Nilsson M, Oreszczyn T, Pye S, Quinn T, Svensdotter M, Venevsky S, Warner K, Xu B, Yang J, Yin Y, Yu C, Zhang Q, Gong P, Montgomery H, Costello A (2015) Health and climate change: policy responses to protect public health. Lancet 386:1861-1914 
Watts N, Amann M, Ayeb-Karlsson S, Belesova K, Bouley T, Boykoff M, Byass P, Cai W, Campbell-Lendrum D, Chambers J, Cox PM, Daly M, Dasandi N, Davies M, Depledge M, Depoux A, Dominguez-Salas P, Drummond P, Ekins P, Flahault A, Frumkin H, Georgeson L, Ghanei M, Grace D, Graham H, Grojsman R, Haines A, Hamilton I, Hartinger S, Johnson A, Kelman I, Kiesewetter G, Kniveton D, Lu L, Lott M, Lowe R, Mace G, Sewe MO, Maslin M, Mikhaylov S, Milner J, Latifi AM, Moradi-Lakeh M, Morrissey K, Murray K, Neville T, Nilsson M, Oreszczyn T, Owfi F, Pencheon D, Pye S, Rabbaniha M, Robinson E, Rocklöv J, Schütte S, Shumake-Guillemot J, Steinbach R, Tabatabaei M, Wheeler N, Wilkinson P, Gong P, Montgomery H, Costello A (2018) The Lancet countdown on health and climate change: from 25 years of inaction to a global transformation for public health. Lancet 391:581-630

Wilkinson P, Campbell-Lendrum D, Bartlett C, Corvalán C, Githeko AK, Woodward A, Scheraga J (2003) Monitoring the health effects of climate change. In

Xun WW, Khan AE, Michael E, Vineis P (2010) Climate change epidemiology: methodological challenges. International Journal of Public Health 55:85-96

Ziska LH, Makra L, Harry SK, Bruffaerts N, Hendrickx M, Coates F, Saarto A, Thibaudon M, Oliver G, Damialis A, Charalampopoulos A, Vokou D, Heiđmarsson S, Guđjohnsen E, Bonini M, Jae-Won O, Sullivan K, Linda F, Daniel Brooks G, Myszkowska D, Severova E, Gehrig R, Ramón GD, Beggs PJ, Knowlton K, Allison R. Crimmins. (2019) Temperature-related changes in airborne allergenic pollen abundance and seasonality across the northern hemisphere: a retrospective data analysis. The Lancet Planetary Health 3:e124-ee31

Publisher's note Springer Nature remains neutral with regard to jurisdictional claims in published maps and institutional affiliations. 